\section{Macroeconomic determinants of fiscal policy in East Africa: a panel causality analysis}

\author{
Joseph Mawejje and Nicholas M. Odhiambo \\ Department of Economics, University of South Africa, Pretoria, South Africa
}

Fiscal policy in East Africa

Abstract

Purpose - This study investigates the dynamic causality linkages between fiscal deficits and selected macroeconomic indicators in a panel of five East African Community countries.

Design/methodology/approach - The research design is based on panel cointegration tests, panel crosssection dependence tests, panel error correction-based Granger causality tests and panel impulse response functions.

Findings - Results show that there is long-run feedback causality among fiscal deficits and each of the variables include gross domestic product (GDP) growth, current account balance, interest rates, inflation, grants and debt service. Short-run Granger causality dynamics indicate that there is feedback causality between fiscal deficits and GDP growth; no causality between fiscal deficits and inflation; no causality between fiscal deficits and current account; no causality between fiscal deficits and interest rates; feedback causality between fiscal deficits and grants; and no causality between fiscal deficits and debt service. Impulse response functions show positive and significant impacts of current account balance, inflation and grants; negative and significant impacts of real GDP growth and lending rates; and insignificant effects of debt service.

Research limitations/implications - While the study examines the dynamic causality between fiscal deficits and selected macroeconomic indicators in the East African Community, the analysis excludes South Sudan due to significant data limitations.

Practical implications - In light of the East African Community's aspirations to achieve convergence on key macroeconomic targets, including the fiscal deficit, this research provides novel insights on fiscal policy determinants and causality dynamics.

Social implications - The dynamic relationships between fiscal policy and macroeconomic variables may have social implications for welfare, equitable growth and distribution of resources.

Originality/value - With a focus on the East African Community, this paper contributes to the literature on the macroeconomic determinants of fiscal deficits in regional economic communities.

Keywords Fiscal deficits, Granger causality, Impulse response, Panel data, East Africa

Paper type Research paper

\section{Introduction}

There is continuing interest among scholars and policymakers in the roles that fiscal policy plays in the mobilization and allocation of resources necessary to facilitate the realization of desired economic outcomes consistent with a country's development agenda (MorenoDodson, 2012). However, many developing and emerging market economies have experienced rising budget deficits in recent years, with growing concerns over implications for future fiscal sustainability, debt and macroeconomic stability (Kose et al., 2021). More recently, the coronavirus disease 2019 (COVID-19) pandemic has precipitated

\section{JEL Classification — E62, E63, H61, H62, H63}

(C) Joseph Mawejje and Nicholas M. Odhiambo. Published in Journal of Economics, Finance and Administrative Science. Published by Emerald Publishing Limited. This article is published under the Creative Commons Attribution (CC BY 4.0) licence. Anyone may reproduce, distribute, translate and create derivative works of this article (for both commercial and non-commercial purposes), subject to full attribution to the original publication and authors. The full terms of this licence may be seen at http:// creativecommons.org/licences/by/4.0/legalcode.

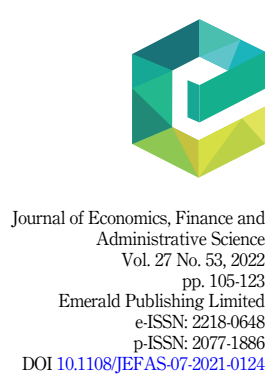


JEFAS

27,53

106 large macroeconomic imbalances, leading to loss of fiscal sustainability across many countries (Burger and Calitz, 2021; Makin and Layton, 2021; Brodeur et al., 2021).

While the literature on the macroeconomic determinants of fiscal deficits is voluminous, however, findings are inconclusive (Saleh and Harvie, 2005). In addition, existing studies have tended to focus on single-country case studies, limiting the generalization of findings to a wider range of country contexts (Mawejje and Odhiambo, 2020). While weak growth and lowinterest rates explained the rising fiscal deficits in the pre-COVID-19 period (World Bank, 2019a), recent experiences suggest more nuanced developments, necessitating new and comprehensive analyses of the determinants of fiscal deficits. Indeed, evidence shows that in comparison to previous periods, the COVID-19 pandemic has precipitated disproportionately larger fiscal deficits and macroeconomic effects (Makin and Layton, 2021; Alberola et al., 2021). At the same time, if rising fiscal deficits result in unsustainable accumulation of debt, then new vulnerabilities would emerge with implications for growth and macroeconomic management (IMF, 2020a).

The purpose of this paper is to investigate the dynamic causality linkages between fiscal deficits and selected macroeconomic indicators. We examine these issues in five East African Community (EAC) member countries, namely Burundi, Kenya, Rwanda, Tanzania and Uganda. The analysis excludes South Sudan due to significant data limitations. The EAC is considered one of the most dynamic African regional economic communities with aspirations of becoming a monetary union (Drummond et al., 2015). Within the regional economic integration framework, EAC member countries agreed upon macroeconomic convergence targets that include inflation, fiscal deficits, debt and interest rates. Specifically, the target for fiscal deficits is $3 \%$ of gross domestic product (GDP), intending to maintain gross public debt levels below $50 \%$ of GDP in net present terms (Ltaifa et al., 2015). However, attaining converge may experience challenges as fiscal deficits have been rising over the past decade leading to the build-up of public debt across the region (IMF, 2018). In addition, emerging vulnerabilities including those related to the COVID-19 pandemic that has affected growth and led to higher financing needs may derail progress amidst heightened global uncertainty (African Development Bank, 2020; IMF, 2020b).

This study contributes to two strands of the literature. First, the study contributes to the literature on the macroeconomic determinants of fiscal deficits. Second, the study contributes to the literature on the macroeconomic effects of fiscal deficits in regional economic communities in developing economies. As has been argued by Papageorgiou et al. (2016), fiscal policy is probably the most important tool in dealing with country-specific fluctuations in a regional economic community. However, devising requisite responses requires a clear understanding of the determinants of fiscal policy and their dynamic causality linkages.

The rest of the paper is organized as follows: Section two provides a review of the literature and develops a simple analytical framework. Methods are discussed in Section three. Section four presents the results. A brief discussion is provided in Section five. Section six concludes.

\section{Literature review}

\subsection{The determinants of fiscal deficits}

From a theoretical perspective, the literature espouses four views that explain fiscal policy outcomes. The Ricardian equivalence theory postulates that fiscal deficits are neither determined nor yield any macroeconomic effects in the long run (Barro, 1989; Seater, 1993). The Keynesian theoretical view links fiscal deficits to investment and growth (Bernheim, 1989; Eisner, 1989). The neoclassical theory describes budget deficits as arising from market lending and borrowing decisions in inter-temporal optimization problems (Bernheim, 1989). This theoretical exposition gives rise to the twin-deficit hypothesis which describes a causal 
linkage between a country's fiscal and current account balances (Kim and Roubini, 2008). The fourth view describes fiscal deficits as arising out of political economy contestations (Alesina and Perotti, 1995; Eslava, 2011).

The empirical literature examining the determinants and effects of fiscal deficits using dynamic causality models is scant but evolving. Employing the Gregory and Hansen cointegration methodology, as well as asymmetric cointegration techniques, Trachanas and Katrakilidis (2013) showed that the twin deficits hypothesis holds for Portugal, Ireland, Greece and Spain. These findings are consistent with research by Xie and Chen (2014) who used bootstrap panel Granger causality methods to show that there is bi-directional causality between the current account deficit and the government budget deficit for eleven Organisation for Economic Co-operation and Development (OECD) countries. However, these results are contrasted by, among others, Sobrino (2013), who used quarterly data and Granger causality methods to reject the twin deficits hypothesis and instead show that current account balances cause fiscal deficits in Peru.

Research examining the dynamic nexus between fiscal deficits and inflation has provided useful insights. Catao and Terrones (2005) investigated the dynamic linkages among fiscal deficits and inflation in a panel of 107 countries over 1960-2001. Using the mean group and pooled mean group estimators within the panel Autoregressive Distributed Lag (ARDL) framework, results showed that budget deficits are significant drivers of inflation among high-inflation and developing country groups, but not among low-inflation advanced economies. These results are consistent with a wide range of literature that shows the positive dynamic relationship between budget deficits and inflation (Bhat and Sharma, 2020; Nguyen, 2015; Lin and Chu, 2013).

Investigations of the dynamic relationship between fiscal deficits and real economic growth have attracted much attention in the literature. Afonso and Jalles (2014) examined the causal dynamics between fiscal policy and economic growth. Using panel Granger causality methods on a large panel of 155 countries for the period 1970-2010, they uncover strong causality running from fiscal policy (government expenditures) to per capita GDP, but no evidence to support Granger causality from per capita GDP to government expenditure. More recently, Magazzino (2016) examined the relationship between fiscal variables and economic growth in panels of economic groups in Sub-Saharan African countries using annual data for the period 1980-2011, finding a positive relationship between the two variables. Specifically, a 1 percentage point reduction in economic growth would widen budget balances by about 0.18 percentage points for the West African Economic and Monetary Union (WAEMU) countries.

Research findings on the dynamic nexus between budget balances and interest rates have been inconclusive. Vamvoukas (2002) used a combination of seemingly unrelated regressions (SUR) and impulse response functions and concluded that bidirectional causality exists between budget deficits and interest rates using data on a small open economy. Cheng (1998) applied the two-step Engle-Granger causality methodology but found no causality between fiscal deficits and long-term interest rates in Japan. However, Cheng (1998) uncovered feedback causality between fiscal deficits and short-term interest rates using Hsiao's approach to causality testing. Uwilingiye and Gupta (2009) concluded that budget deficits Granger cause interest rates in South Africa with no feedback confirmed in a multivariate vector error correction framework. However, García and Ramajo (2004) did not find evidence to support the validity of causality between budget deficits and interest rates in Spain using error correction methods within the ARDL framework.

The literature shows that access to grants and loans has important implications for fiscal policy (Morrissey, 2015). There has consequently emerged an interesting thread of literature examining the fiscal effects of aid in developing countries. Within this realm, Bwire et al. (2017a) examined the dynamic causal links among aid and fiscal variables in Uganda, over 
JEFAS

27,53

108 the period 1972 to 2014 using a cointegrated vector autoregressive (CVAR) model with both annual and quarterly data. Importantly, they show that these variables form a stable long-run cointegrated relationship, implying causality in at least one direction. These findings are consistent with recent analyses on Ethiopia (Mascagni and Timmis, 2017), Rwanda (Bwire et al., 2017b) and Ghana (Osei et al., 2005).

More recent analyses have focused on the determinants of fiscal policies in the wake of the COVID-19 crisis. Within this realm, Benmelech and Tzur-Ilan (2020) showed that low-income countries with poor credit ratings had smaller fiscal space to respond more meaningfully to the crisis than high-income countries. In Africa, the fiscal effects of the pandemic are estimated to be especially severe with estimates indicating that fiscal deficits doubled in 2020 leading to increased debt burdens (African Development Bank, 2021). For many countries, however, the pandemic exacerbated an already precarious fiscal position, with depleted buffers offering limited space to manoeuvre, leading to loss of fiscal sustainability (Burger and Calitz, 2021; Makin and Layton, 2021; Brodeur et al., 2021). To restore fiscal sustainability, governments may consider growth-enhancing budget-neutral reallocation of expenditures, reliance on external grants and concessional lending, while avoiding inflationary financing of the budget (Loayza and Pennings, 2020).

\subsection{Econometric framework}

This study proposes a framework in which fiscal deficits are determined through the interaction of activities of households, government and external sector developments.

The household sector. The current study presents a representative household that maximizes an inter-temporal utility function that is dependent on the consumption of a homogenous good, defined in equation (1).

$$
\sum_{t=0}^{\infty} \beta^{t} U\left(C_{t}\right)
$$

where $C_{t}$ refers to a consumption basket, and $\beta^{t}$ is the subjective discount factor, such that $(0<\beta<1)$, i.e. $\beta$ is strictly positive (non-negative) and less than unity. $U$ defines a utility function that is assumed to be strictly increasing and concave in consumption.

Following earlier work that modelled household intertemporal budget constraints in general models for fiscal deficit determination, the study makes the following assumptions: (1) that the household is endowed with a positive quantity of a good $Y_{t}$; (2) that the household pays taxes $\tau_{t}$ and can either consume or transfer the after-tax endowment over time by money holdings or through risk-free bonds (Catao and Terrones, 2005). Therefore, the household's inter-temporal budget constraint can be constructed as defined in equation (2).

$$
C_{t}+\frac{b_{t+1}^{p}}{R_{t}^{*}}+\frac{m_{t+1}}{p_{t}}=y_{t}-\tau_{t}+b_{t}^{p}+\frac{m_{t}}{p_{t}}
$$

where $C_{t}$ is household consumption defined as previously; $b_{t}^{p}$ represents the real value of household-held risk-free bonds; $m_{t+1}$ represents household's holding of money balances; $\tau_{t}$ is a lumpsum tax at period $t ; p_{t}$ is the price level and $R_{t}^{*}$ is the international real gross rate of return on one-period bonds. Rearranging equation (2), and defining inflation as $\frac{m_{t+1}}{p_{t}}-\frac{m_{t}}{p_{t}}=\pi_{t}$ or a change in prices, and $\frac{b_{t+1}^{p}}{R_{t}^{*}}-b_{t}^{p}=\Delta \frac{b_{t}^{p}}{R_{t}^{*}}$ defined as the real change in household holdings of real bonds, we can then define the household budget constraint as shown in equation (3). In this postulation, for a given level of income, consumption and taxes, the household budget deficit can be defined as a function of holdings of real bonds and inflation. Please note that the 
stock of bonds that a household can hold at any time, $t$ can be expressed as a function of real disposable income and interest rate (or the return on bonds), such that:

$$
\frac{b_{t+1}^{p}}{R_{t}^{*}}-b_{t}^{p}=\Delta \frac{b_{t}^{p}}{R_{t}^{*}}=f\left(i_{t}, \pi_{t}\right)
$$

Substituting equation (3) into equation (2) yields the optimal household budget constraint which can be thought of as a function of interest rates, defined as the return on governmentissued debt/bonds, $i_{t}$ and inflation, $\pi_{t}$ as shown in equation (4):

$$
y_{t}-C_{t}-\tau_{t}=f\left(i_{t}, \pi_{t}\right)
$$

The government sector. In each period, government fulfils its budgetary obligations either by collecting taxes, issuing debt, running down reserves or printing money. Governments can also receive transfers or grants in the form of Overseas Development Assistance (ODA). Drawing from the public finance and fiscal sustainability analysis literature (Blanchard, 1985; Taylor et al., 2012), the government inter-temporal budget constraint can be defined as:

$$
D_{t}=D_{t-1}+i D_{t-1}-B_{t}-R_{t}
$$

where $D_{t}$ is the stock of public debt that includes both domestic and foreign debt; $i$ is the average nominal interest rate; $B_{t}$ is the budget balance defined as the difference between $T_{t}$ and primary expenditure $S_{t}$; and $R_{t}$ is access to grants. Assuming that nominal GDP growth is $g$, i.e. $G D P_{t}=(1+g) * G D P_{t-1}$, equation (5) can be divided by $G D P_{t}$ and rearranged to obtain equation (6).

$$
\Delta d_{t}=\left[\frac{(i-g)}{(i+g)}\right] d_{t-1}-\left(t_{t}-s_{t}\right)-r_{t}
$$

Rearranging equation (6) yields the government budget deficit as a function of GDP growth rate, interest rates, debt and access to foreign grants as shown in equation (7). Specifically, equation (7) shows that budget deficits will be higher, the higher are interest rates; the lower is growth; the higher is debt (or debt servicing flows), and the higher are grants.

$$
\left(t_{t}-s_{t}\right)=\left[\frac{(i-g)}{(i+g)}\right] d_{t-1}-\Delta d_{t}-r_{t}
$$

The external sector. The current account balance reflects a country's external position with the rest of the world. In this respect, the Mundell-Fleming model, based on the seminal works of Mundell (1963) and Fleming (1962), provides a useful starting point and building blocks for the relationship between fiscal policy and the external sector. Building on the MundellFleming framework, Abbas et al. (2011) provide a framework in which fiscal policy and the current account are represented using the following identity in equation (8):

$$
c a_{t}=t b_{t}+t p_{t} \equiv\left(S_{p t}-I_{p t}\right)+\left(S_{g t}-I_{g t}\right)
$$

where $c a_{t}$ represents the current account; $t b_{t}$ is the trade balance; $t b_{t}$ are transfer payments. $S_{p t}$ and $I_{p t}$ are private savings and investment respectively; $S_{g t}$ and $I_{g t}$ are government savings and investment respectively. In the absence of government transfers to the private sector, $S_{g t}-I_{g t}$ is equivalent to the fiscal balance. In this respect, therefore, the budget balance, $b_{t}$, can be expressed as a function of the current account balance $c a_{t}$ and the private savingsinvestment gap $\left(S_{p t}-I_{p t}\right)$, such that: 
JEFAS

27,53

110

$$
b_{t}=f\left(c a_{t}, S_{p t}-I_{p t}\right)
$$

Drawing from various theoretical underpinnings, including the accelerator principle and the saving and investment literature (Samuelson, 1939); intertemporal saving and investment models (Abel and Blanchard, 1983); and the intertemporal postulation of current account dynamics (Obstfeld and Rogoff, 1995), savings and investments are related to the GDP growth rate, $g_{t}$, and interest rates, $i_{t}$. Thus, equation (9) can be reformulated in terms of the current account, $c a_{t}$; real GDP growth rate, $g_{t}$ and interest rates, $i_{t}$, as shown in equation (10).

$$
b_{t}=f\left(c a_{t}, i_{t}, g_{t}\right)
$$

The general model. Combining the determinants of budget balances from the household, government and external sectors into a single model yields the following general model (equation 11) that provides a useful framework for carrying out an empirical evaluation of the determinants of fiscal deficits in a given country:

$$
b_{t}=f\left(i_{t}, g_{t}, d_{t}, r_{t}, c a_{t}, \pi_{t}\right)
$$

Hypotheses. This general model specifies the determinants of fiscal deficits as interest rates, real GDP growth rate, debt (or debt service), grants, current account balance and inflation. Following the general model specified in equation (11), the following testable hypotheses are investigated:

H1. Current account does not Granger cause fiscal deficits;

H2. Real GDP growth does not Granger cause fiscal deficits;

H3. Inflation does not Granger cause fiscal deficits;

H4. Interest rate does not Granger cause fiscal deficits;

H5. Grants do not Granger cause fiscal deficits;

H6. Debt service does not Granger cause fiscal deficits.

\section{Method}

\subsection{Data collection}

The study constructed a balanced panel dataset, spanning 38 years during 1980-2017, from annual time series data for each of the five East African countries considered in this study. Specifically, the study considers the following variables, chosen as appropriate from a review of extant literature as well as well availability of full and consistent data for all the countries: fiscal deficits (\% GDP), current account balance (\% GDP), real GDP growth; interest rates; debt service ( $\% \mathrm{GDP})$ and grants ( $\% \mathrm{GDP})$. Fiscal and current account balances data are sourced from the IMF's World Economic Outlook (IMF, 2019). Real GDP growth rates, interest rates, public debt service, grants and inflation data are sourced from the World Bank's (2019b) World Development Indicators (WDI). Table 1 summarizes the variables used in this study, including their definitions and sources. The descriptive statistics are provided in Table 2.

\subsection{Research design}

Panel unit root tests. To ascertain the levels of integration of the variables, this study performed three unit root tests that include Im-Pesaran-Shin; Levin-Lin-Chu and Fishertype Philips-Perron tests. The test results provided in Table 3 show that all variables are integrated of the first order, I(1). 


\begin{tabular}{|c|c|c|c|c|}
\hline Variable & Name & Definition & Source & \\
\hline Fiscal deficit & FDEF & $\begin{array}{l}\text { The difference between revenue and expenditure, } \\
\text { excluding grants and interest payments, expressed as a } \\
\text { percentage of GDP }\end{array}$ & $\operatorname{IMF}(2019)$ & \\
\hline Interest rate & LRATE & Return on government issued debt or bonds & $\begin{array}{l}\text { World Bank } \\
(2019 \mathrm{~b})\end{array}$ & \\
\hline $\begin{array}{l}\text { Real GDP } \\
\text { growth }\end{array}$ & RGDP & $\begin{array}{l}\text { Year-on-year change in a country's real GDP, expressed as } \\
\text { a percentage }\end{array}$ & $\begin{array}{l}\text { World Bank } \\
\text { (2019b) }\end{array}$ & 111 \\
\hline Debt service & DEBT & $\begin{array}{l}\text { The percentage debt service of expressed as a percentage } \\
\text { of GDP in any given year }\end{array}$ & $\begin{array}{l}\text { World Bank } \\
\text { (2019b) }\end{array}$ & \\
\hline Grants & GRANT & $\begin{array}{l}\text { Official bilateral and multilateral non-repayable loans } \\
\text { received expressed as a percentage of GDP }\end{array}$ & $\begin{array}{l}\text { World Bank } \\
\text { (2019b) }\end{array}$ & \\
\hline $\begin{array}{l}\text { Current account } \\
\text { balance }\end{array}$ & $\mathrm{CAB}$ & $\begin{array}{l}\text { The difference between a country's value of exports and } \\
\text { imports of goods, services, and transfer payments, } \\
\text { expressed as a percentage of GDP }\end{array}$ & $\mathrm{IMF}(2019)$ & \\
\hline Inflation rate & INFLATION & $\begin{array}{l}\text { Year-on-year change in a country's consumer price index } \\
(2010=100) \text {, expressed as a percentage }\end{array}$ & $\begin{array}{l}\text { World Bank } \\
(2019 b)\end{array}$ & $\begin{array}{r}\text { Table } 1 . \\
\begin{array}{r}\text { Definitions and sources } \\
\text { of variables }\end{array}\end{array}$ \\
\hline
\end{tabular}

\begin{tabular}{lrrrrr}
\hline & Mean & Std. dev & Min & Max & $N$ \\
\hline Fiscal deficit, \% GDP & -9.332 & 6.035 & -33.100 & 0.400 & 190 \\
Current account, \% GDP & -5.427 & 5.183 & -26.230 & 11.420 & 190 \\
Real GDP growth, \% & 4.143 & 5.384 & -41.890 & 24.540 & 190 \\
Interest rates, \% & 18.917 & 6.438 & 10.580 & 42.830 & 190 \\
Inflation, \% & 17.457 & 29.018 & -2.420 & 215.400 & 190 \\
Debt service, \% GDP & 2.740 & 2.578 & 0.210 & 12.990 & 190 \\
Grants, \% GDP & 4.476 & 4.529 & 0.090 & 22.645 & 190
\end{tabular}

Source(s): Own elaboration

Table 2.
Descriptive statistics

\begin{tabular}{|c|c|c|c|c|c|c|c|}
\hline \multirow[b]{2}{*}{ Variable } & \multicolumn{2}{|c|}{ Levin-Lin-Chu } & \multicolumn{2}{|c|}{ Im-Pesaran-Shin } & \multicolumn{2}{|c|}{ Fisher type (ADF) } & \multirow[b]{2}{*}{$\begin{array}{l}\text { Order of } \\
\text { integration }\end{array}$} \\
\hline & In levels & $\begin{array}{c}\text { In first } \\
\text { differences }\end{array}$ & $\begin{array}{c}\text { In } \\
\text { levels }\end{array}$ & $\begin{array}{c}\text { In first } \\
\text { differences }\end{array}$ & $\begin{array}{l}\text { In } \\
\text { levels }\end{array}$ & $\begin{array}{c}\text { In first } \\
\text { differences }\end{array}$ & \\
\hline FDEF & -0.714 & $-9.899 * * *$ & -1.257 & $-10.947 * * *$ & 14.864 & $111.244 * * *$ & $\mathrm{I}(1)$ \\
\hline LRATE & -0.585 & $-4.601 * * *$ & -1.065 & $-5.871 * * *$ & 12.485 & $53.610^{* * * *}$ & I (1) \\
\hline RGDP & 0.756 & $-4.160 * * *$ & 2.908 & $-5.162 * * *$ & 1.061 & $47.616 * * *$ & I (1) \\
\hline DEBT & -0.241 & $-8.768 * * *$ & 0.137 & $-8.394 * * *$ & 9.185 & $81.737^{* * * *}$ & I (1) \\
\hline GRANT & -0.386 & $-9.895 * * *$ & -1.378 & $-8.990 * * *$ & 14.825 & $89.530 * * *$ & I (1) \\
\hline $\mathrm{CAB}$ & -0.223 & $-8.004 * * *$ & -1.097 & $-9.828 * * *$ & 14.439 & $98.421 * * *$ & I (1) \\
\hline CPI & $-3.513 * * *$ & & -0.424 & $-2.172^{* *}$ & 14.933 & $21.723 * *$ & I (1) \\
\hline
\end{tabular}

Note(s): (1) Tabulated are test statistics; (2) *,** and *** denote statistical significance at the $10 \%, 5 \%$ and $1 \%$ levels, respectively; (3) For all unit root tests the null hypothesis is specified as follows: Ho: Panels contain unit roots; (4) All tests are carried out including individual intercept and trend

Source(s): Own elaboration

Table 3.

Panel unit root tests

Panel cointegration tests. This study performs cointegration tests based on Pedroni (1999, 2004). These test procedures investigate the null hypothesis of no cointegration, against the alternative hypothesis that the variables are cointegrated in all panels. It is important to note 
JEFAS

27,53

112

that the tests are restricted to a maximum of seven covariates in the underlying panel regressions. Pedroni's co-integration test results in Table 4 show that, except for the panel vstatistic in panel A and group-rho statistics in panel B, all other statistics are significant, so the null hypothesis of no cointegration is rejected.

Panel-based cross-section dependence tests. The literature indicates that panel-data models are likely to suffer cross-section dependence in their error terms. This may be due to some reasons including spatial dependence, idiosyncratic pairwise dependence in the disturbances, the presence of common shocks and unobserved components that may be absorbed in the error term (Pesaran, 2021; Baltagi, 2005; Anselin, 2001). Crosssection dependence was shown to decrease estimation efficiency significantly and the usefulness of panel estimators over single equation least-squares methods may be lost (Phillips and Sul, 2003).

This study carried out two cross-section dependence tests suggested by Pesaran (2021) and Frees (1995) to ensure that cross-country correlations are not present and to avoid inconsistent parameter estimation. The general null hypothesis is in these tests is that the errors for the estimated panel regression are uncorrelated, that is, allowing to test the hypothesis that there is no cross-section dependence in the panel data. The test results for cross-sectional dependence are provided in Table 5. Results show that the null hypothesis of no cross-section dependence cannot be rejected based on the Pesaran and Frees tests. This study, therefore, concludes that there is no cross-section dependence based on the Pesaran and Frees test results.

\subsection{Analytical procedures}

Investigations of the dynamic causal relationship among variables can be traced to the seminal work of Granger (1969) who developed a bivariate causality testing framework based on time series data. More recently, Dumitrescu and Hurlin (2012) developed a procedure for

\begin{tabular}{lcccr}
\multicolumn{2}{l}{ Panel A: Pedroni cointegration tests: Alternative hypothesis: common } & AR coefs. (within-dimension) \\
& Statistic & Prob & Weighted Statistic & Prob \\
\hline Panel v-Statistic & 1.192 & 0.117 & -0.689 & 0.754 \\
Panel rho-Statistic & -2.374 & 0.009 & -1.927 & 0.027 \\
Panel PP-Statistic & -5.834 & 0.000 & -5.614 & 0.000 \\
Panel ADF-Statistic & -1.351 & 0.088 & -1.859 & 0.031
\end{tabular}

Panel B: Pedroni cointegration tests: Alternative hypothesis: individual AR coefs. (between-dimension)

Statistic Prob

$\begin{array}{llrr} & & -1.161 & 0.122 \\ \text { Table 4. } & \text { Group PP-Statistic } & -6.107 & 0.000\end{array}$

$\begin{array}{llr}\text { Panel Group ADF-Statistic } & -1.902 & 0.028\end{array}$

cointegration tests Source(s): Own elaboration

Table 5.

Cross-section dependence tests results

\begin{tabular}{lcc}
\hline & Test statistics & Probability \\
\hline Pesaran's test & 0.031 & 0.975 \\
Frees' test & 0.038 & 0.482 \\
Source(s): Own elaboration & & \\
\hline
\end{tabular}


implementing pairwise Granger causality tests in panel datasets. In this framework, a variable, say $Y_{i t}$, is said to Granger cause another variable, say, $Z_{i t}$ if, given the past information or values of $Z_{i t}$, past values of $Y_{i t}$ are useful in predicting $Z_{i t}$. A convenient way for testing Granger causality involves regressing $Z_{i t}$ on its owned lagged values and lagged values of $Y_{i t}$ and test for the joint significance of the estimated coefficients on $Y_{i t}$. If the coefficients on $Y_{i t}$ are non-zero, then we can conclude that $Y_{i t}$ Granger causes $Z_{i t}$, that is past information in $Y_{i t}$ can be used to predict $Z_{i t}$.

However, pairwise Granger causality testing has been criticized for disregarding the short-run adjustment mechanisms that exist in level relationships. Therefore, these tests could suffer significant misspecification biases unless the lagged error correction terms are included if the variables are cointegrated (Granger, 1988). Importantly, these tests do not allow testing for both short-run and long-run Granger causality in a single framework. Moreover, these tests might suffer omitted variable bias if other control variables are not included. Multivariate Granger causality testing allows us to circumvent such shortcomings by including, as additional control variables, the differenced lagged values of all variables under consideration, in a panel ARDL error correction framework.

Following Engle and Granger (1987), we use a two-step procedure to implement multivariate panel Granger causality testing. The first step involves estimating a pooled longrun model in levels to generate the estimated residuals. This is done by estimating a system of models represented in equation (12).

$$
\begin{aligned}
F D E F_{i t}= & \alpha_{0}+\alpha_{1 t} L_{R A T E_{i t}}+\alpha_{2 t} R G D P_{i t}+\alpha_{3 t} D E B T_{i t}+\alpha_{4 t} G R A N T_{i t}+\alpha_{5 t} C A B_{i t} \\
& +\alpha_{6 t} \text { INFLATION }_{i t}+\varepsilon_{i t}
\end{aligned}
$$

The second step involves using the lagged residuals from equation (1) above as the error correction terms in a panel ARDL system of equations used to test for both short-run and long-run multivariate Granger causality. This system of models is expressed in equations (13)-(19).

$$
\begin{aligned}
\Delta F D E F_{i t}= & \mu_{i}+\sum_{j=1}^{p} \alpha_{11, i j} \Delta F D E F_{i, t-j}+\sum_{j=1}^{q} \alpha_{12, i j} \Delta L R A T E_{i, t-j}+\sum_{j=0}^{q} \alpha_{13, i j} \Delta R G D P_{i, t-j} \\
& +\sum_{j=0}^{q} \alpha_{14, i j} \Delta D E B T_{i, t-j}+\sum_{j=0}^{q} \alpha_{15, i j} \Delta G R A N T_{i, t-j}+\sum_{j=0}^{q} \alpha_{16, i j} \Delta C A B_{i, t-j} \\
& +\sum_{j=0}^{q} \alpha_{17, i j} \Delta \operatorname{INFLATION}_{i, t-j}+\beta_{1 i} E C T_{i, t-1}+\varepsilon_{i t} \\
\Delta L R A T E_{i t}= & \mu_{i}+\sum_{j=1}^{p} \alpha_{21, i j} \Delta L R A T E_{i, t-j}+\sum_{j=0}^{q} \alpha_{22, i j} \Delta F D E F_{i, t-j}+\sum_{j=0}^{q} \alpha_{23, i j} \Delta R G D P_{i, t-j} \\
& +\sum_{j=0}^{q} \alpha_{24, i j} \Delta D E B T_{i, t-j}+\sum_{j=0}^{q} \alpha_{25, i j} \Delta G R A N T_{i, t-j}+\sum_{j=0}^{q} \alpha_{26, i j} \Delta C A B_{i, t-j} \\
& +\sum_{j=0}^{q} \alpha_{27, i j} \Delta I N F L A T I O N_{i, t-j}+\beta_{2 i} E C T_{i, t-1}+\varepsilon_{i t}
\end{aligned}
$$

Fiscal policy in East Africa 
JEFAS

27,53

114

$$
\begin{aligned}
\Delta R G D P_{i t}= & \mu_{i}+\sum_{j=1}^{p} \alpha_{31, i j} \Delta R G D P_{i, t-j}+\sum_{j=0}^{q} \alpha_{32, i j} \Delta F D E F_{i, t-j}+\sum_{j=0}^{q} \alpha_{33, i j} \Delta L R A T E_{i, t-j} \\
& +\sum_{j=0}^{q} \alpha_{34, i j} \Delta D E B T_{i, t-j}+\sum_{j=0}^{q} \alpha_{35, i j} \Delta G R A N T_{i, t-j}+\sum_{j=0}^{q} \alpha_{36, i j} \Delta C A B_{i, t-j} \\
& +\sum_{j=0}^{q} \alpha_{37, i j} \Delta I N F L A T I O N_{i, t-j}+\beta_{3 i} E C T_{i, t-1}+\varepsilon_{i t}
\end{aligned}
$$

$$
\begin{aligned}
\Delta D E B T_{i t}= & \mu_{i}+\sum_{j=1}^{p} \alpha_{41, i j} \Delta D E B T_{i, t-j}+\sum_{j=0}^{q} \alpha_{42, i j} \Delta F D E F_{i, t-j}+\sum_{j=0}^{q} \alpha_{43, i j} \Delta L R A T E_{i, t-j} \\
& +\sum_{j=0}^{q} \alpha_{44, i j} \Delta R G D P_{i, t-j}+\sum_{j=0}^{q} \alpha_{45, i j} \Delta G R A N T_{i, t-j}+\sum_{j=0}^{q} \alpha_{46, i j} \Delta C A B_{i, t-j} \\
& +\sum_{j=0}^{q} \alpha_{47, i j} \Delta \operatorname{INFLATION}_{i, t-j}+\beta_{4 i} E C T_{i, t-1}+\varepsilon_{i t}
\end{aligned}
$$

$$
\begin{aligned}
\Delta G R A N T_{i t}= & \mu_{i}+\sum_{j=1}^{p} \alpha_{51, i j} \Delta G R A N T_{i, t-j}+\sum_{j=0}^{q} \alpha_{52, i j} \Delta F D E F_{i, t-j}+\sum_{j=0}^{q} \alpha_{53, i j} \Delta L R A T E_{i, t-j} \\
& +\sum_{j=0}^{q} \alpha_{54, i j} \Delta G R A N T_{i, t-j}+\sum_{j=0}^{q} \alpha_{55, i j} \Delta D E B T_{i, t-j}+\sum_{j=0}^{q} \alpha_{56, i j} \Delta C A B_{i, t-j} \\
& +\sum_{j=0}^{q} \alpha_{57, i j} \Delta I N F L A T I O N_{i, t-j}+\beta_{5 i} E C T_{i, t-1}+\varepsilon_{i t}
\end{aligned}
$$$$
\Delta C A B_{i t}=\mu_{i}+\sum_{j=1}^{p} \alpha_{61, i j} \Delta C A B_{i, t-j}+\sum_{j=0}^{q} \alpha_{62, i j} \Delta F D E F_{i, t-j}+\sum_{j=0}^{q} \alpha_{63, i j} \Delta L R A T E_{i, t-j}
$$$$
+\sum_{j=0}^{q} \alpha_{64, i j} \Delta R G D P_{i, t-j}+\sum_{j=0}^{q} \alpha_{65, i j} \Delta D E B T_{i, t-j}+\sum_{j=0}^{q} \alpha_{66, i j} \Delta G R A N T_{i, t-j}
$$$$
+\sum_{j=0}^{q} \alpha_{67, i j} \Delta I N F L A T I O N_{i, t-j}+\beta_{6 i} E C T_{i, t-1}+\varepsilon_{i t}
$$

$\Delta$ INFLATION $_{i t}=\mu_{i}+\sum_{j=1}^{p} \alpha_{71, i j} \Delta$ INFLATION $_{i, t-j}+\sum_{j=0}^{q} \alpha_{72, i j} \Delta F D E F_{i, t-j}$

$$
\begin{aligned}
& +\sum_{j=0}^{q} \alpha_{73, i j} \Delta L R A T E_{i, t-j}+\sum_{j=0}^{q} \alpha_{74, i j} \Delta R G D P_{i, t-j}+\sum_{j=0}^{q} \alpha_{75, i j} \Delta D E B T_{i, t-j} \\
& +\sum_{j=0}^{q} \alpha_{76, i j} \Delta G R A N T_{i, t-j}+\sum_{j=0}^{q} \alpha_{77, i j} \Delta C A B_{i, t-j}+\beta_{7 i} E C T_{i, t-1}+\varepsilon_{i t}
\end{aligned}
$$

All variables are as previously defined, $\Delta$ denotes the first difference for each variable, ECT denotes the error correction term, $p$ is the lag length of the autoregression, $q$ is the lag of the distributed lags. Based on the error correction formulation in equations (2)-(8), we test for both 
short-run and long-run panel multivariate Granger causality between fiscal deficits and the vector of endogenous regressors included in the model. Short-run Granger causality is tested by the joint Wald $F$ test for coefficient restrictions. Long-run Granger causality is tested by a $t$ test of the $\beta$ coefficients for the ECT for each panel multivariate function once a long-run relationship is confirmed.

In addition to the panel error correction-based Granger causality tests, the study considers a dynamic panel autoregressive distributed lag model that is specified as shown in equation (20).

$$
F D E F_{i t}=A(L) F D E F_{i t}+B(L) Z_{i t}+\varepsilon_{i t}
$$

where $F D E F$ is described as before, $Z_{i t}$ is a vector of other macroeconomic variables included in the model and $\varepsilon_{i t}$ are disturbances that are assumed to be independently and identically distributed. $A(L)$ and $B(L)$ are the $p t h$ and $q$ th order lag operators with $p \geq 1$ and with $q \geq 0$. In the benchmark model, we use $p=1$ and $q=1$.

The richness of our dataset provides critical advantages. Specifically, the dynamic feature of the panel autoregressive distributed lag model allows us to use impulse response functions to capture the dynamic relationships among budget deficits and selected macroeconomic variables. The impulse response function is given by the expression in equation (21).

$$
\operatorname{IRF}(L)=B(L) / 1-A(L)
$$

\section{Results}

\subsection{Multivariate panel granger causality analysis}

In examining the multivariate panel Granger causality dynamics, the study followed the Engle and Granger (1987) two-step procedure. The first step involves estimating seven long-run models in levels using pooled panel regressions (see equation 12). These models are then used to generate residuals that represent the long-run cointegrating vector. The second step involves using the lagged residuals generated in equation (12) as the error correction terms in a system of equations used to test for both short-run and long-run multivariate Granger Causality. Long-run causality is inferred when the lagged errorcorrection terms are negative and statistically significant. In addition, their absolute values should be less than unity, which confirms convergence to a stable long-run stable relationship. Short-run causality is inferred by the joint significance of each of the shortrun parameters included in the model.

Results in Table 6 indicate that there is long-run feedback causality between fiscal deficits and current account balance; fiscal deficits and real GDP growth; fiscal deficits and inflation; fiscal deficits and interest rates; fiscal deficits and grants; and fiscal deficits debt service. This is confirmed by the statistically significant error correction terms in each of the models in our system of equations. These results contribute to the literature that has examined the dynamic causal linkages between fiscal deficits and current account (Abbas et al., 2011); real GDP growth (Adam and Bevan, 2005; Kim et al., 2021); inflation (Lin and Chu, 2013); interest rates (Aisen and Hauner, 2013); grants (Mascagni and Timmis, 2017; Osei et al., 2005) and debt service (Maltritz and Wüste, 2015).

Short-run Granger causality dynamics indicate mixed results. Results indicate that there is bi-directional short-run causality between fiscal deficits and GDP growth. Further, results indicate no short-run causality between fiscal deficits and inflation; no short-run causality between fiscal deficits and current account; no short-run causality between fiscal deficits and interest rates; two-way short-run causality between fiscal deficits and grants; and no short- 
JEFAS

27,53

116

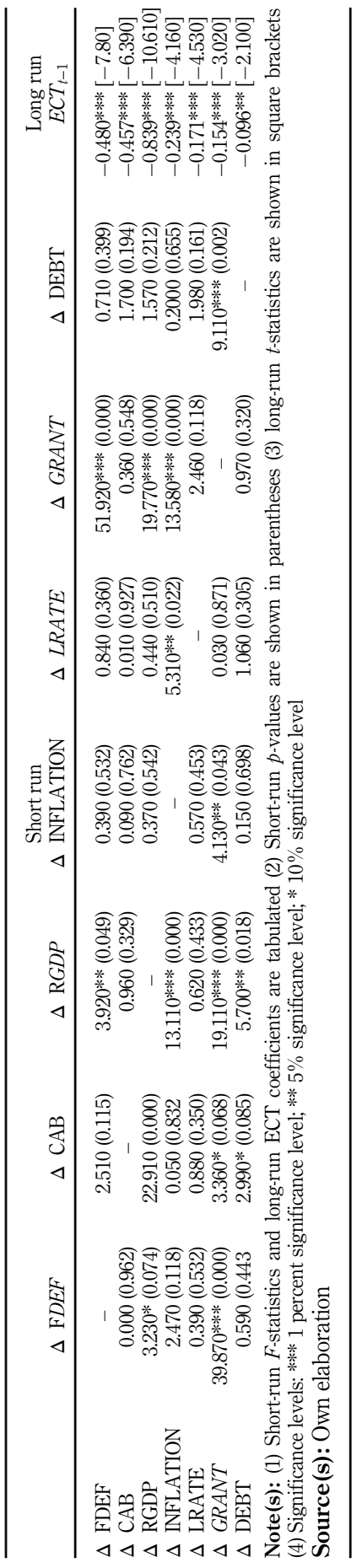

Table 6.

Multivariate Granger causality test results 
run causality between fiscal deficits and debt service. Table 7 provides a summary of the direction of causality from the multivariate panel Granger causality tests.

\subsection{Impulse response functions}

Results from the impulse response functions are qualitatively similar to those from the multivariate Granger causality analysis (see Figure 1). The effect of the current account balance on the fiscal deficit is positive and statistically significant. A one standard deviation shock in the natural logarithm of the current account increases the fiscal balance, with this effect reaching its peak in the third period (year) before becoming insignificant after the fourth year. This finding is consistent with literature showing the positive association between fiscal deficits and current account balance (Kumhof and Laxton, 2013; Kim and Roubini, 2008).

Results further show that the effect of a positive GDP growth shock on fiscal deficits is negative, with this effect reaching its peak in the third period (year) before turning insignificant in the fourth year. The divergent relationship between these two variables indicates that fiscal policy is countercyclical. This finding is contrary to the dominant literature showing that fiscal policy tends to be pro-cyclical in developing countries (Carmignani, 2010; Kassouri and Altıntaş, 2021). However, the findings of this study are consistent with Thornton (2007) who showed that South African fiscal policy is countercyclical.

Results further show that the effect of a positive inflation shock is positive and statistically significant. Specifically, the effect of inflation reaches its peak in the second year and thereafter dies out and becomes insignificant by the third year. These results are consistent with Lis and Nickel (2010) who showed a statistically significant and positive relationship between inflation and budget balances. between infla
Fiscal policy in East Africa

\begin{tabular}{|c|c|c|c|}
\hline No & Null hypothesis & Short run & Long run \\
\hline 1 & $\begin{array}{l}\text { Current account does not Granger cause fiscal } \\
\text { deficits }\end{array}$ & $C A B \neq D E F I C I T$ & $C A B \rightarrow D E F I C I T$ \\
\hline 2 & $\begin{array}{l}\text { Fiscal deficits do not Granger cause current } \\
\text { account }\end{array}$ & $D E F I C I T \neq C A B$ & $D E F I C I T \rightarrow C A B$ \\
\hline 3 & $\begin{array}{l}\text { Real GDP growth does not Granger cause } \\
\text { fiscal deficits }\end{array}$ & GROWTH $\rightarrow$ DEFICIT & GROWTH $\rightarrow$ DEFICIT \\
\hline 4 & $\begin{array}{l}\text { Fiscal deficits do not Granger cause real GDP } \\
\text { growth }\end{array}$ & DEFICIT $\rightarrow$ GROWTH & DEFICIT $\rightarrow$ GROWTH \\
\hline 5 & $\begin{array}{l}\text { Inflation does not Granger cause fiscal } \\
\text { deficits }\end{array}$ & INFLATION $\neq$ DEFICIT & INFLATION $\rightarrow$ DEFICIT \\
\hline 6 & Fiscal deficits do not Granger cause inflation & $D E F I C I T \neq I N F L A T I O N$ & DEFICIT $\rightarrow$ INFLATION \\
\hline 7 & $\begin{array}{l}\text { Interest rate differential does not Granger } \\
\text { cause fiscal deficits }\end{array}$ & $L R A T E \neq D E F I C I T$ & $L R A T E \rightarrow D E F I C I T$ \\
\hline 8 & $\begin{array}{l}\text { Fiscal deficits do not Granger cause interest } \\
\text { rate differential }\end{array}$ & $D E F I C I T \neq L R A T E$ & DEFICIT $\rightarrow$ LRATE \\
\hline 9 & Grants do not Granger cause fiscal deficits & GRANT $\rightarrow$ DEFICIT & GRANT $\rightarrow$ DEFICIT \\
\hline 10 & Fiscal deficits do not Granger cause grants & $D E F I C I T \rightarrow G R A N T$ & $D E F I C I T \rightarrow G R A N T$ \\
\hline 11 & $\begin{array}{l}\text { Debt service does not Granger cause fiscal } \\
\text { deficits }\end{array}$ & $D E B T \neq D E F I C I T$ & $D E B T \rightarrow D E F I C I T$ \\
\hline 12 & $\begin{array}{l}\text { Fiscal deficits do not Granger cause debt } \\
\text { service }\end{array}$ & $D E F I C I T \neq D E B T$ & $D E F I C I T \rightarrow D E B T$ \\
\hline
\end{tabular}


JEFAS

27,53

\section{8}

Figure 1.

Impulse response functions
Response to Cholesky One S.D. (d.f. adjusted) Innovations

\pm 2 analytic asymptotic S.E.S

Response of FDEF to CAB Innovation

Response of FDEF to RGDP Innovation

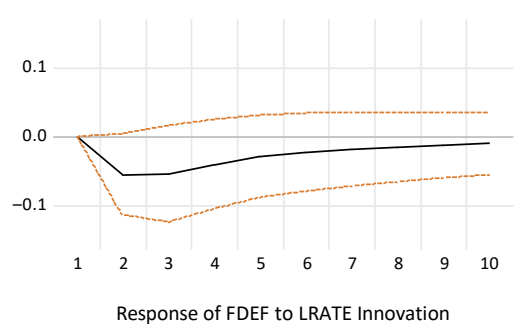

Response of FDEF to INFLATION Innovation

Response of FDEF to LRATE Innovation

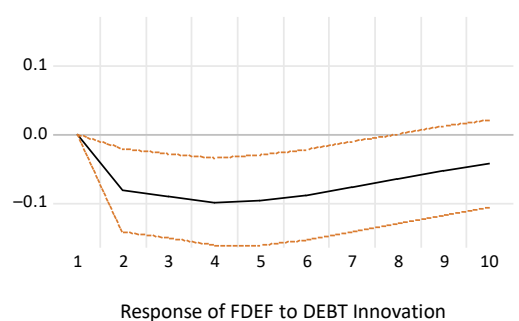

Response of FDEF to GRANT Innovation

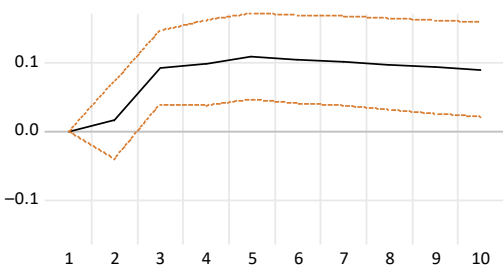

Source(s): Own elaboration

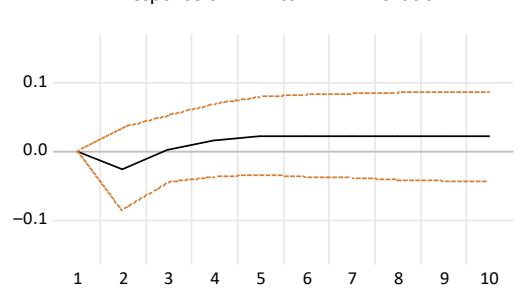

A positive shock to interest rates leads to a statistically significant reduction of the fiscal deficit. This effect reaches its maximum in the fourth year but is statistically significant until the seventh year. This implies that governments run larger budget deficits in response to lower interest rates and smaller deficits in response to higher interest rates. These results are consistent among others, Uwilingiye and Gupta (2009), who showed similar effects using South African time series data. In addition, results show that grants have a positive and persistent effect on fiscal deficits. However, the impact of debt service on budget balances is modest and insignificant.

\section{Discussion}

The EAC member states aspire to deepen economic integration, with a policy commitment to achieving convergence on key macroeconomic indicators. Regarding fiscal policy, the target is to achieve a deficit of about 3\% of GDP. However, budget deficits have been rising over the past years raising concerns over increasing debt vulnerabilities. These fiscal vulnerabilities have been exacerbated by the ongoing COVID-19 shock and the weakened global outlook. While the fiscal policy is expected to play a critical role for COVID-19 economic recovery, it will play an even more important role in dealing with country-specific shocks as the countries deepen regional integration and prepare to ascend to a monetary union in the medium term. 
This study provided a better understanding of the dynamic linkages among fiscal deficits and key macroeconomic variables among EAC member countries.

The results of this study have significant social and practical implications. First, the dynamic relationships between fiscal policy and macroeconomic variables have social implications for welfare, equitable growth and the distribution of resources. Second, findings provide novel insights into fiscal policy determinants and causality dynamics considering the EAC's aspirations to achieve macroeconomic convergence targets. Finally, policymakers may find these results useful given the role fiscal policy is expected to play in supporting economic recovery in the wake of the COVID-19 crisis. Future research may consider examining the cyclicality of fiscal policy while differentiating between the revenue and expenditure components.

\section{Conclusions}

This study investigated the dynamic causality linkages among fiscal deficits and selected macroeconomic indicators in East Africa. Specifically, the paper considered the effects of real GDP growth, interest rates, grants, inflation, current account balances and debt service requirements. After deriving testable hypotheses from a simple analytical framework, the econometric analysis used two separate but complementary methodological approaches: (1) panel error correction-based Granger causality tests and (2) panel impulse response functions.

Results confirm that there is long-run feedback causality between fiscal deficits and each one of the explanatory variables included in the study. Short-run Granger causality dynamics show that there is a two-way short-run causality between fiscal deficits and GDP growth. Further, results indicate no short-run causality running from fiscal deficits to inflation; no short-run causality between fiscal deficits and current account; no short-run causality between fiscal deficits and interest rates; two-way short-run causality between fiscal deficits and grants; and no short-run causality between fiscal deficits and debt service.

Impulse response function results are qualitatively similar to Granger causality test results, confirming the robustness of our findings. Specifically, impulse response functions show positive and significant short-run impacts of current account balance, inflation and interest rates; negative impacts short-run of real GDP growth and lending rates; and insignificant short-run effects of debt service.

In order to maintain fiscal sustainability in the wake of increasing global and internal shocks, EAC countries should implement policies to spur real GDP growth, maintain macroeconomic stability with low inflation and external sector sustainability. Further, in the context of diminished fiscal space, the authorities should prioritize growth-enhancing budget-neutral reallocation of expenditures, reliance on external grants and concessional lending, and avoid inflationary financing of public deficits.

\section{References}

Abbas, S.A., Bouhga-Hagbe, J., Fatás, A., Mauro, P. and Velloso, R.C. (2011), "Fiscal policy and the current account", IMF Economic Review, Vol. 59 No. 4, pp. 603-629, doi: 10.1057/imfer.2011.22.

Abel, A.B. and Blanchard, O.J. (1983), "An intertemporal model of saving and investment", Econometrica, Vol. 51 No. 3, pp. 675-692, doi: 10.2307/1912153.

Adam, C.S. and Bevan, D.L. (2005), "Fiscal deficits and growth in developing countries", Journal of Public Economics, Vol. 89 No. 4, pp. 571-597, doi: 10.1016/j.jpubeco.2004.02.006.

Afonso, A. and Jalles, J.T. (2014), "Causality for the government budget and economic growth", Applied Economics Letters, Vol. 21 No. 17, pp. 1198-1201, doi: 10.1080/13504851.2014.916383. 
JEFAS

27,53

120

African Development Bank (2020), "Coping with COVID-19 pandemic", East African Economic Outlook 2020, African Development Bank Group, Abidjan.

African Development Bank (2021), "From debt resolution to growth: the road ahead for Africa", African Economic Outlook 2021, African Development Bank Group, Abidjan.

Aisen, A. and Hauner, D. (2013), "Budget deficits and interest rates: a fresh perspective", Applied Economics, Vol. 45 No. 17, pp. 2501-2510, doi: 10.1080/00036846.2012.667557.

Alberola, E., Arslan, Y., Cheng, G. and Moessner, R. (2021), "Fiscal response to the COVID-19 crisis in advanced and emerging market economies", Pacific Economic Review, Vol. 26 No. 4, pp. 459-468, doi: 10.1111/1468-0106.12370.

Alesina, A. and Perotti, R. (1995), "The political economy of budget deficits", IMF Economic Review, Vol. 42 No. 1, pp. 1-31, doi: 10.2307/3867338.

Anselin, L. (2001), "Spatial econometrics", in Baltagi, B.H. (Ed.), A Companion to Theoretical Econometrics, Blackwell Scientific Publications, Oxford, pp. 310-330.

Baltagi, B.H. (2005), Econometric Analysis of Panel Data, 3rd ed., Wiley, New York.

Barro, R.J. (1989), "The Ricardian approach to budget deficits", Journal of Economic Perspectives, Vol. 3 No. 2, pp. 37-54, doi: 10.1257/jep.3.2.37.

Benmelech, E. and Tzur-Ilan, N. (2020), The Determinants of Fiscal and Monetary Policies during the COVID-19 Crisis, Working Paper 27461, National Bureau of Economic Research, Cambridge.

Bernheim, B.D. (1989), "A neoclassical perspective on budget deficits", Journal of Economic Perspectives, Vol. 3 No. 2, pp. 55-72, doi: 10.1257/jep.3.2.55.

Bhat, J.A. and Sharma, N.K. (2020), "Identifying fiscal inflation in India-some recent evidence from an asymmetric approach", Journal of Economics, Finance and Administrative Science, Vol. 25 No. 50, pp. 363-393, doi: 10.1108/JEFAS-03-2019-0032.

Blanchard, O.J. (1985), "Debt, deficits, and finite horizons", Journal of Political Economy, Vol. 93 No. 2, pp. 223-247, doi: 10.1086/261297.

Brodeur, A., Gray, D., Islam, I. and Bhuiyan, S. (2021), "A literature review of the economics of COVID19”, Journal of Economic Surveys, Vol. 35 No. 4, pp. 1007-1044, doi: 10.1111/joes.12423.

Burger, P. and Calitz, E. (2021), "Covid-19, economic growth and South African fiscal policy", South African Journal of Economics, Vol. 89 No. 1, pp. 3-24, doi: 10.1111/saje.12270.

Bwire, T., Lloyd, T. and Morrissey, O. (2017a), "Fiscal reforms and the fiscal effects of aid in Uganda", The Journal of Development Studies, Vol. 53 No. 7, pp. 1019-1036, doi: 10.1080/00220388.2017. 1303677.

Bwire, T., Tamwesigire, C. and Munyankindi, P. (2017b), "Fiscal effects of aid in Rwanda", in Heshmati, A. (Ed.), Studies on Economic Development and Growth in Selected African Countries. Frontiers in African Business Research, Springer, Singapore, doi: 10.1007/978-981-10-4451-9_5.

Carmignani, F. (2010), "Cyclical fiscal policy in Africa”, Journal of Policy Modeling, Vol. 32 No. 2, pp. 254-267, doi: 10.1016/j.jpolmod.2010.01.002.

Catao, L.A. and Terrones, M.E. (2005), "Fiscal deficits and inflation", Journal of Monetary Economics, Vol. 52 No. 3, pp. 529-554, doi: 10.1016/j.jmoneco.2004.06.003.

Cheng, B.S. (1998), "The causality between budget deficit and interest rates in Japan: an application of time series analysis", Applied Economics Letters, Vol. 5 No. 7, pp. 419-422, doi: 10.1080/135048598354546.

Drummond, M.P., Aisen, M.A., Alper, M.C.E., Fuli, M.E. and Walker, M.S. (2015), Toward a Monetary Union in the East African Community: Asymmetric Shocks, Exchange Rates, and Risk-Sharing Mechanisms, International Monetary Fund, Washington DC, doi: 10.5089/9781513562179.087.

Dumitrescu, E.I. and Hurlin, C. (2012), "Testing for Granger non-causality in heterogeneous panels", Economic Modelling, Vol. 29 No. 4, pp. 1450-1460, doi: 10.1016/j.econmod.2012.02.014.

Eisner, R. (1989), "Budget deficits: rhetoric and reality", Journal of Economic Perspectives, Vol. 3 No. 2, pp. 73-93, doi: 10.1257/jep.3.2.73. 
Engle, R.F. and Granger, C.W. (1987), "Co-integration and error correction: representation, estimation, and testing", Econometrica, Vol. 55 No. 2, pp. 251-276, doi: 10.2307/1913236.

Eslava, M. (2011), "The political economy of fiscal deficits: a survey”, Journal of Economic Surveys, Vol. 25 No. 4, pp. 645-673, doi: 10.1111/j.1467-6419.2010.00647.x.

Fleming, M.J. (1962), "Domestic financial policies under fixed and under floating exchange rates", IMF Economic Review, Vol. 9, pp. 369-380, doi: 10.2307/3866091.

Frees, E.W. (1995), "Assessing cross-sectional correlation in panel data”, Journal of Econometrics, Vol. 69 No. 2, pp. 393-414, doi: 10.1016/0304-4076(94)01658-M.

García, A. and Ramajo, J. (2004), "Budget deficit and interest rates: empirical evidence for Spain", Applied Economics Letters, Vol. 11 No. 11, pp. 715-718, doi: 10.1080/1350485042000236593.

Granger, C.W. (1969), "Investigating causal relations by econometric models and cross-spectral methods", Econometrica, Vol. 37 No. 3, pp. 424-438, doi: 10.2307/1912791.

Granger, C.W. (1988), "Some recent development in a concept of causality", Journal of Econometrics, Vol. 39 Nos 1-2, pp. 199-211, doi: 10.1016/0304-4076(88)90045-0.

IMF (2018), Fiscal Monitor: Capitalizing on Good Times, International Monetary Fund, Washington, DC.

IMF (2019), World Economic Outlook Database October 2019, International Monetary Fund, Washington, DC.

IMF (2020a), The Evolution of Public Debt Vulnerabilities in Lower Income Economies, Policy Paper No. 20/003, International Monetary Fund, Washington, DC.

IMF (2020b), “A Difficult Road to Recovery”, Regional Economic Outlook: Sub-saharan Africa, International Monetary Fund, Washington, DC.

Kassouri, Y. and Altıntaş, H. (2021), "Cyclical drivers of fiscal policy in sub-Saharan Africa: new insights from the time-varying heterogeneity approach", Economic Analysis and Policy, Vol. 70, pp. 51-67, doi: 10.1016/j.eap.2021.01.019.

Kim, S. and Roubini, N. (2008), "Twin deficit or twin divergence? Fiscal policy, current account, and real exchange rate in the US", Journal of International Economics, Vol. 74 No. 2, pp. 362-383, doi: 10.1016/j.jinteco.2007.05.012.

Kim, J., Wang, M., Park, D. and Petalcorin, C.C. (2021), "Fiscal policy and economic growth: some evidence from China", Review of World Economics, Vol. 157, pp. 555-582, doi: 10.1007/s10290021-00414-5.

Kose, M.A., Nagle, P., Ohnsorge, F. and Sugawara, N. (2021), Global Waves of Debt: Causes and Consequences, World Bank, Washington DC, doi: 10.1596/978-1-4648-1544-7.

Kumhof, M. and Laxton, D. (2013), "Fiscal deficits and current account deficits", Journal of Economic Dynamics and Control, Vol. 37 No. 10, pp. 2062-2082, doi: 10.1016/j.jedc.2013.05.001.

Lin, H.Y. and Chu, H.P. (2013), "Are fiscal deficits inflationary?", Journal of International Money and Finance, Vol. 32, pp. 214-233, doi: 10.1016/j.jimonfin.2012.04.006.

Lis, E.M. and Nickel, C. (2010), "The impact of extreme weather events on budget balances", International Tax and Public Finance, Vol. 17 No. 4, pp. 378-399, doi: 10.1007/s10797-010-9144-x.

Loayza, N.V. and Pennings, S. (2020), Macroeconomic Policy in the Time of COVID-19: A Primer for Developing Countries, Research and Policy Briefs, No. 28, World Bank, Washington, DC.

Ltaifa, N.B., Yabara, M. and Willias, O. (2015), "Economic convergence to support the East african monetary union", in Drummond et al. (Ed.), The Quest for Regional Integration in the East African Community, International Monetary Fund, Washington, DC, doi: 10.5089/ 9781484364413.071.

Magazzino, C. (2016), "Fiscal variables and growth convergence in the ECOWAS", African Journal of Economic and Management Studies, Vol. 7 No. 2, pp. 147-163, doi: 10.1108/AJEMS-03-2015-0032.
Fiscal policy in East Africa 
JEFAS

27,53

Makin, A.J. and Layton, A. (2021), "The global fiscal response to COVID-19: risks and repercussions", Economic Analysis and Policy, Vol. 69, pp. 340-349, doi: 10.1016/j.eap.2020.12.016.

Maltritz, D. and Wüste, S. (2015), "Determinants of budget deficits in Europe: the role and relations of fiscal rules, fiscal councils, creative accounting and the Euro", Economic Modelling, Vol. 48, pp. 222-236, doi: 10.1016/j.econmod.2014.12.001.

Mascagni, G. and Timmis, E. (2017), "The fiscal effects of aid in Ethiopia: evidence from CVAR applications", The Journal of Development Studies, Vol. 53 No. 7, pp. 1037-1056, doi: 10.1080/ 00220388.2017.1303676.

Mawejje, J. and Odhiambo, N.M. (2020), "The determinants of fiscal deficits: a survey of literature", International Review of Economics, Vol. 67 No. 3, pp. 403-417, doi: 10.1007/s12232-020-00348-8.

Moreno-Dodson, B. (2012), Is Fiscal Policy the Answer? A Developing Country Perspective, The World Bank, Washington DC, doi: 10.1596/978-0-8213-9630-8.

Morrissey, O. (2015), “Aid and government fiscal behavior: assessing recent evidence”, World Development, Vol. 69, pp. 98-105, doi: 10.1016/j.worlddev.2013.12.008.

Mundell, R.A. (1963), “Capital mobility and stabilizing policy under fixed and flexible exchange rates", Canadian Journal of Economics and Political Science, Vol. 29, pp. 475-485, doi: 10.2307/139336.

Nguyen, V.B. (2015), "Effects of fiscal deficit and money M2 supply on inflation: evidence from selected economies of Asia”, Journal of Economics, Finance and Administrative Science, Vol. 20 No. 38, pp. 49-53, doi: 10.1016/j.jefas.2015.01.002.

Obstfeld and Rogoff, K. (1995), "The intertemporal approach to the current account", Handbook of International Economics, Vol. 3, pp. 1731-1799, doi: 10.1016/S1573-4404(05)80014-0.

Osei, R., Morrissey, O. and Lloyd, T. (2005), "The fiscal effects of aid in Ghana", Journal of International Development, Vol. 17 No. 8, pp. 1037-1053, doi: 10.1002/jid.1258.

Papageorgiou, T., Michaelides, P.G. and Tsionas, E.G. (2016), "Business cycle determinants and fiscal policy: a Panel ARDL approach for EMU”, The Journal of Economic Asymmetries, Vol. 13, pp. 57-68, doi: 10.1016/j.jeca.2015.12.001.

Pedroni, P. (1999), "Critical values for cointegration tests in heterogeneous panels with multiple regressors", Oxford Bulletin of Economics and Statistics, Vol. 61 No. S1, pp. 653-670, doi: 10. 1111/1468-0084.0610s1653.

Pedroni, P. (2004), "Panel cointegration: asymptotic and finite sample properties of pooled time series tests with an application to the PPP hypothesis", Econometric Theory, Vol. 20 No. 3, pp. 597-625, doi: 10.1017/S0266466604203073.

Pesaran, M.H. (2021), "General diagnostic tests for cross-sectional dependence in panels", Empirical Economics, Vol. 60, pp. 13-50, doi: 10.1007/s00181-020-01875-7.

Phillips, P.C. and Sul, D. (2003), "Dynamic panel estimation and homogeneity testing under cross section dependence", The Econometrics Journal, Vol. 6 No. 1, pp. 217-259, doi: 10.1111/1368423X.00108.

Saleh, A.S. and Harvie, C. (2005), "The budget deficit and economic performance: a survey", The Singapore Economic Review, Vol. 50 No. 02, pp. 211-243, doi: 10.1142/S0217590805001986.

Samuelson, P.A. (1939), "A synthesis of the principle of acceleration and the multiplier", Journal of Political Economy, Vol. 47 No. 6, pp. 786-797, doi: 10.1086/255469.

Seater, J.J. (1993), "Ricardian equivalence”, Journal of Economic Literature, Vol. 31 No. 1, pp. 142-190, available at: https://www.jstor.org/stable/2728152.

Sobrino, C.R. (2013), "The twin deficits hypothesis and reverse causality: a short run analysis of Peru", Journal of Economics, Finance and Administrative Science, Vol. 18 No. 34, pp. 9-15, doi: 10.1016/ S2077-1886(13)70018-0.

Taylor, L., Proano, C.R., de Carvalho, L. and Barbosa, N. (2012), "Fiscal deficits, economic growth and government debt in the USA", Cambridge Journal of Economics, Vol. 36 No. 1, pp. 189-204, doi: 10.1093/cje/ber041. 
Thornton, J. (2007), "On the cyclicality of South African fiscal policy", South African Journal of Economics, Vol. 75 No. 2, pp. 258-264, doi: 10.1111/j.1813-6982.2007.00114.x.

Trachanas, E. and Katrakilidis, C. (2013), "The dynamic linkages of fiscal and current account deficits: new evidence from five highly indebted European countries accounting for regime shifts and asymmetries”, Economic Modelling, Vol. 31, pp. 502-510, doi: 10.1016/j.econmod.2012.12.026.

Uwilingiye, J. and Gupta, R. (2009), "Temporal causality between budget deficit and interest rate: the case of South Africa", The Indian Economic Journal, Vol. 57 No. 2, pp. 79-96, doi: 10.1177/ 0019466220090206.

Vamvoukas, G.A. (2002), "Budget deficits and interest rates in a small open", International Economic Journal, Vol. 16 No. 2, pp. 31-36, doi: 10.1080/10168730200000011.

World Bank (2019a), Global Economic Prospects: Heightened Tensions, Subdued Investment, World Bank, Washington, DC, doi: 10.1596/978-1-4648-1398-6.

World Bank (2019b), World Development Indicators (WDI) Online, The World Bank Group, Washington, DC, available at: http://datatopics.worldbank.org/world-development-indicators/.

Xie, Z and Chen, S.W. (2014), "Untangling the causal relationship between government budget and current account deficits in OECD countries: evidence from bootstrap panel Granger causality", International Review of Economics and Finance, Vol. 31, pp. 95-104, doi: 10.1016/j.iref.2014. 01.014 .

\section{Corresponding author}

Joseph Mawejje can be contacted at: jmawejje@gmail.com

For instructions on how to order reprints of this article, please visit our website:

www.emeraldgrouppublishing.com/licensing/reprints.htm

Or contact us for further details: permissions@emeraldinsight.com 